\title{
RECENZJE WYDAWNICZE PODRECCZNIKA ANTONIEGO SMOLUKA PT. „ANALIZA MATEMATYCZNA”
}

\author{
Marian Matłoka \\ Uniwersytet Ekonomiczny w Poznaniu
}

DOI: $10.15611 / \mathrm{dm} .2016 .13 .09$.

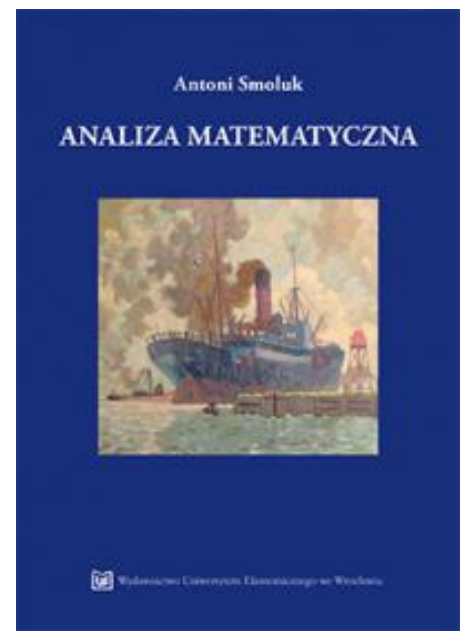

Recenzowany podręcznik „Analiza matematyczna” jest kolejnym podręcznikiem autorstwa prof. Antoniego Smoluka. Podobnie jak podręcznik „Algebra liniowa”, ze względu na zaprezentowane przez Autora podejście do przedstawianych zagadnień, nie jest to tylko podręcznik akademicki, lecz również cenna pozycja naukowa. Na ponad 270 stronach Autor prezentuje wiadomości z zakresu przestrzeni topologicznych, funkcji, ciągów i szeregów liczbowych i funkcyjnych, rachunku różniczkowego funkcji jednej i wielu zmiennych, równań różniczkowych i różnicowych. Jest to znakomite kompendium wiedzy niezbędnej każde$\mathrm{mu}$, kto pragnie skorzystać z aparatu analizy matematycznej. Dobór materiału oaz sposób jego prezentacji świadczą o bardzo dużym doświadczeniu dydaktycznym Autora. Dużą zaletą podręcznika jest staranne przygotowanie wykresów, tabel, rysunków i przykładów objaśniających istotę podawanych definicji i faktów.

Recenzowany podręcznik jest zgodny z programem nauczania, a jego przydatność do procesu dydaktycznego nie podlega dyskusji.

Uważam, że przedstawiony mi do recenzji podręcznik spełnia wszystkie wymagania stawiane przez Wydawnictwo tego typu pozycjom. Jestem głęboko przekonany, że znajdzie on uznanie u czytelników zainteresowanych problematyką analizy matematycznej.

Poznań, dnia 24 września 2016 r.

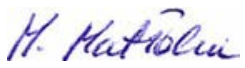




\section{Jerzy Mika Uniwersytet Ekonomiczny w Katowicach}

\section{Podstawa opracowania recenzji}

Umowa o dzieło NR / W-330-1-561/2016 zawarta w dniu 08.09.2016 r. pomiędzy Uniwersytetem Ekonomicznym we Wrocławiu, reprezentowanym przez Prorektora ds. Nauki prof. zw. dr. hab. Jerzego Niemczyka, a recenzentem.

\section{Zakres recenzowanego opracowania}

Przedstawiony do recenzji tekst podręcznika naukowego, będący dziełem Profesora Antoniego Smoluka, jest twórczym rozszerzeniem i logicznym uzupełnieniem wydanego w roku 2007 przez Wydawnictwo Akademii Ekonomicznej we Wrocławiu podręcznika „Podstawy analizy matematycznej" tego samego Autora. Treść dzieła obejmuje wyczerpujący zakres zagadnień, począwszy od ogólnej problematyki przestrzeni topologicznych i metrycznych poprzez klasyczne zagadnienia analizy matematycznej do równań różniczkowych i różnicowych. Mistrzowsko zrealizowany wybór poszczególnych zagadnień jest niewątpliwie autorską, w pełni oryginalną koncepcją podręcznika naukowego $\mathrm{z}$ przedmiotowego zakresu. Całość składa się z przedmowy oraz piętnastu rozdziałów merytorycznych, skorowidza nazw, indeksu nazwisk i skorowidza symboli. Przedmowa ma charakter eseju filozoficznego, stanowi pasjonujące wprowadzenie do treści zasadniczych zawartych w poszczególnych rozdziałach i zawiera szeroki katalog trafnie dobranych i precyzyjnie zestawionych uwag ogólnych i objaśnień szczegółowych, których wyraźną intencją jest ułatwienie zrozumienia treści przedstawionego podręcznika.

W ramach poszczególnych rozdziałów, będących starannie wyodrębnionymi zagadnieniami szczegółowymi z zakresu analizy matematycznej, Autor konsekwentnie stosuje własny, oryginalny sposób narracji polegający na zidentyfikowaniu i uzasadnieniu genezy każdego rozpatrywanego zagadnienia, po czym następuje precyzyjne i dogłębne wyjaśnienie istoty rozpatrywanej problematyki. Warto również podkreślić, że w tym zakresie język wypowiedzi Autora jest niezwykle precyzyjny, zwięzły, jednoznaczny i przy tym w pełni wyczerpujący. Teksty poszczególnych rozdziałów zawierają też trafnie dobrane, sugestywne przykłady znakomicie ilustrujące sferę 
teoretyczną rozpatrywanej problematyki oraz oryginalne odniesienia o szerszym charakterze metodologicznym, a nawet filozoficznym. Autorska logika wywodów prowadzi też do kończenia każdego rozdziału zestawem znakomicie wyselekcjonowanego zbioru zadań do samodzielnego rozwiązania. Zadania często zawierają istotne wskazówki dla czytelnika, każdorazowo podawane są rozwiązania. Zadania te można traktować jako obiektywny test stopnia zrozumienia treści poszczególnych rozdziałów.

W konsekwencji z pełnym przekonaniem oceniam, że opiniowane dzieło Profesora Antoniego Smoluka jest opracowaniem o bezprecedensowo oryginalnej, wyraźnie określonej koncepcji własnej i spełnia najwyższe standardy wymagane od podręczników i monografii z zakresu analizy matematycznej, a korekty, uzupełnienia i rozszerzenia w stosunku do pierwowzoru są każdorazowo uzasadnione oraz podnoszą precyzję i jasność tekstu.

\section{Uwagi ogólne i szczegółowe}

Recenzowany tekst podręcznika naukowego pt. „Analiza matematyczna” napisanego przez Profesora Antoniego Smoluka, jest w pełni oryginalnym oraz autentycznie twórczym przedstawieniem i opracowaniem precyzyjnie wyodrębnionego obszaru naukowego z zakresu najważniejszych tematów stanowiących analizę matematyczną. Autorski dobór przedstawionego materiału oraz sposób realizacji przyjętych koncepcji są silnie zindywidualizowane, charakteryzują się podejściem interdyscyplinarnym i mają istotne znaczenie teoretyczne, a także praktyczne. Kierując się tymi przesłankami, uważam, że opiniowane dzieło to przede wszystkim klasyczna i autentyczna monografia naukowa o bezprecedensowym znaczeniu poznawczym, która może być również wykorzystywana jako podręcznik naukowy z zakresu analizy matematycznej.

Pod względem formalnym i merytorycznym do opiniowanego dzieła nie mam zastrzeżeń o charakterze ogólnym. Mam natomiast szczegółowe spostrzeżenia, wątpliwości, kontrowersje oraz własne uwagi krytyczne i polemiczne zarówno do formy, jak i treści niektórych fragmentów przedstawionego do oceny tekstu, które przedstawię obecnie w kilku oddzielnych punktach.

\section{Ocena zakresu tematycznego}

Zrealizowany przez Autora obszar tematyczny ocenianego dzieła uważam za ustalony na poprawnych założeniach formalnych i merytorycznych. Ponadto przyjęty zakres tematyczny jest adekwatny do aktualnych i perspektywicznych programów studiów ekonomicznych i odpowiada aktual- 
nemu stanowi wiedzy w zakresie analizy matematycznej. Autorski dobór tematyki z przedmiotowego zakresu oraz konsekwentnie realizowana oryginalna konwencja realizacji przyjętych koncepcji dały w efekcie wyraźne zindywidualizowanie i jednoznacznie korzystne odróżnienie recenzowanego dzieła od wszystkich innych znanych mi polskich i zagranicznych podręczników i monografii z zakresu analizy matematycznej.

\section{Ocena kompozycji pracy}

Zastosowany przez Autora podział zasadniczej części opiniowanego dzieła, analogicznie jak pierwowzoru, na piętnaście odrębnych rozdziałów jest mym zdaniem merytorycznie uzasadniony i nie budzi kontrowersji. Kolejność poszczególnych rozdziałów jest logiczna i niepodważalna, a treści rozdziałów odpowiednio się uzupełniają i przenikają się wzajemnie. Stwierdzam ponadto, że proporcje między poszczególnymi rozdziałami są moim zdaniem logicznie uzasadnione. Na szczególne wyróżnienie w tym zakresie zasługuje też oryginalność i harmonia akcentów, jakie Autor nadał poszczególnym tematom szczegółowym, co w znacznym stopniu stanowi o oryginalności i wysokiej jakości opiniowanego dzieła.

\section{Ocena sposobu przedstawienia materiału}

Cały tekst recenzowanego podręcznika naukowego czyta się lekko, swobodnie, doznając fascynującego i pięknego wrażenia uczestniczenia w misterium odkrywania prawdy o otaczającym świecie. Jest to niewątpliwy efekt wszechogarniającej wielkiej erudycji Autora, który mistrzowsko posługując się piękną polszczyzną i fachową terminologią naukową, sprawnie, swobodnie i zręcznie formułuje swe myśli, oceny, wnioski i zalecenia. Narracja przebiega przy tym zawsze, niezależnie od poziomu ogólności, zwięźle, a jednoczenie precyzyjnie i wyczerpująco.

\section{Ocena zastosowanej terminologii}

Fachowa terminologia matematyczna i ekonomiczna oraz stosowane przez Autora oznaczenia i symbole nie są kontrowersyjne i nie budzą wątpliwości, gdyż są na ogół standardowe. Ponadto do tekstu wprowadzono, moim zdaniem, uzasadnioną ilość fachowych terminów i oznaczeń, w konsekwencji nie odczuwa się więc żadnych braków i zbędnych powtórzeń w tym zakresie.

\section{Ocena calkowitej objętości pracy}

Tekst opiniowanego dzieła oceniam jako bardzo starannie wyważony. „Analiza matematyczna” napisana przez Profesora Antoniego Smoluka to 
dzieło kompletne i wyczerpujące, a jednocześnie zwarte i zwięzłe, co jest ewidentnym efektem najwyższych kompetencji merytorycznych Autora w zakresie matematyki oraz jego wybitnego talentu pisarskiego i filozoficznej wnikliwości.

\section{Ocena doboru jakościowego rysunków}

Rysunki w przedstawionym tekście występują raczej rzadko, ale zawsze wtedy, gdy są niezbędne i mogą dodatkowo wyjaśniać wywody słowne. Ponadto oceniam, że rysunki są dobrze wybrane, właściwie zredagowane i starannie wykonane. W kontrowersyjnych przypadkach, zwłaszcza dotyczących numeracji rysunków, uwagi w tym zakresie zgłaszam w dalszej części niniejszej opinii lub na marginesie tekstu pracy.

\section{Postulaty i uwagi dla Autora}

Z zaszczytnego obowiązku recenzenta wybitnego dzieła Profesora Antoniego Smoluka zgłaszam ponadto następujące dodatkowe postulaty szczegółowe dla Autora $\mathrm{z}$ wnioskiem o ich rozważenie i ewentualne uwzględnienie.

1. Uważam [nadal], że numeracja rysunków $w$ tekście powinna być podwójna (nr rozdz. nr rys.), bowiem tylko wtedy zapewniona będzie jednoznaczność numerów rysunków.

2. Sadze, że diagram na stronie 218 jest rysunkiem i tak powinien być traktowany.

3. Uważam, że warto doprecyzować opisy rysunków 2 i 4 na stronach 213 i 223.

4. Wzór występujący częściowo na stronie 103, a częściowo na stronie 104 powinien być przeredagowany.

5. Pozycja symbolu całki oznaczonej na stronie 138 powinna być skorygowana tak, by wzór byt czytelny.

6. Na rysunku 1 na stronie 114 powinny być uzupetnione granice catkowania.

7. Opisy niektórych rysunków na ss. 35-36, 39-40, 176-177, 181-182 powinny być przeniesione na tę sama strone co rysunek.

8. Numery niektórych stron [79, 111, 129, 171, 189, 190, 209, 253, 254] wystepuja dwukrotnie, co powinno być skorygowane.

Zauważyłem ponadto jeszcze kilka innych drobnych kwestii wątpliwych, dyskusyjnych i kontrowersyjnych, niemających jednak istotnego znaczenia merytorycznego. Uwagi te zaznaczyłem więc jedynie ołówkiem w tekście i na marginesie wydruku recenzowanego dzieła. 


\section{Wnioski końcowe}

Recenzowany podręcznik naukowy - monografia naukowa - „Analiza matematyczna” autorstwa Profesora Antoniego Smoluka jest twórczym rozszerzeniem i logicznym uzupełnieniem wydanego w roku 2007 pierwowzoru. Za szczególnie cenne uważam te korekty i uzupełnienia, które zawarto na stronach: 31, 75, 161, 172, 182-184, 216. Opiniowane dzieło oceniam analogicznie jak pierwowzór, jako oryginalne z zakresu współczesnej analizy matematycznej, będące znakomitą syntezą trafnie wyselekcjonowanych problemów teoretycznych i ekonomicznych zastosowań analizy matematycznej. Tekst charakteryzuje się oryginalnym wyborem piętnastu odrębnych, szczegółowych zagadnień teoretycznych połączonych w logiczną i spójną całość. Swoista i spójna logika opiniowanego podręcznika naukowego pozwala uważnemu czytelnikowi dostrzec piękno głębi i oryginalności koncepcji Autora dzieła, które jest syntezą aktualnego stanu wiedzy w zakresie analizy matematycznej oraz twórczych koncepcji własnych Autora. Ponadto przedstawiony tekst podręcznika w pełnym zakresie jest zgodny z obowiązującymi programami nauczania analizy matematycznej na studiach ekonomicznych i pokrewnych. Pod względem dydaktycznym podręcznik naukowy „Analiza matematyczna” spełnia najwyższe światowe standardy w tym zakresie i może obecnie i w przyszłości wzorowo pełnić funkcję nowatorskiego podręcznika dla studentów uczelni ekonomicznych. $\mathrm{W}$ porównaniu $\mathrm{z}$ innymi znanymi mi podręcznikami polskimi i zagranicznymi z zakresu analizy matematycznej opiniowane dzieło wyróżnia się przede wszystkim oryginalnością koncepcji, precyzją realizacji i twórczym podejściem do podejmowanej tematyki. Z tych względów opracowanie Profesora Antoniego Smoluka można z pełną odpowiedzialnością określić jako podręcznik XXI wieku i rekomendować jako podręcznik szczególnie przydatny dla procesu dydaktycznego w uczelniach wyższych.

Reasumując, stwierdzam jednoznacznie, że recenzowany podręcznik naukowy „Analiza matematyczna” autorstwa Profesora Antoniego Smoluka, ze względu na oryginalność jego koncepcji oraz wysoki poziom naukowy i dydaktyczny, powinien być opublikowany w przedstawionej wersji, bez zmian w zakresie koncepcji ogólnej, lecz po ewentualnym zrewidowaniu i uwzględnieniu wymienionych wyżej szczegółowych kwestii redakcyjnych.

Katowice, 28.09.2016

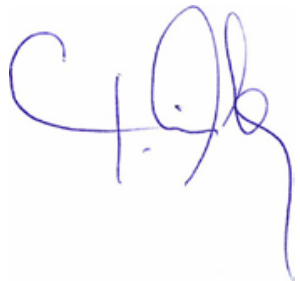

